\title{
IMPLEMENTASI SUPERVISI AKADEMIK KEPALA SEKOLAH UNTUK MENINGKATKAN KINERJA GURU
}

\author{
${ }^{1}$ Leniwati dan ${ }^{2}$ Yasir Arafat \\ ${ }^{1}$ Guru SMA Negeri 1 Sembawa Banyuasin \\ ${ }^{2}$ Dosen Program Studi Magister Manajemen Pendidikan, Universitas PGRI Palembang \\ e-mail : lenidarmawi@yahoo.com
}

\begin{abstract}
The purpose of this research was to obtain information about the implementation of academic supervision done by the headmaster in order to develop teachers' performance. This research used qualitative method. Data were collected through interview, observation and documentation. The subjects of this research were the headmaster and the teachers. The results showed that the implementation of the academic supervision was done on three steps were planning, implementation and evaluation. The teachers gave positive responses to the implementation of academic supervision.
\end{abstract}

Keywords: Academic Supervision, Headmaster, Teachers' Performance

\section{PENDAHULUAN}

Pendidikan merupakan hal yang sangat penting dalam kehidupan karena dengan pendidikan dapat mencerdaskan kehidupan dan membentuk watak bangsa. Hal ini sesuai dengan fungsi dan tujuan pendidikan nasional yang terdapat dalam UU No. 20 Tahun 2003 tentang Sistem Pendidikan Nasional yaitu pendidikan nasional berfungsi mengembangkan kemampuan dan membentuk watak serta peradaban dalam rangka mencerdaskan kehidupan bangsa, bertujuan untuk berkembangnya potensi peserta didik agar menjadi manusia yang beriman dan bertaqwa kepada Tuhan Yang Maha Esa, berakhlak mulia, sehat, berilmu, cakap, kreatif, mandiri, dan menjadi warga negara yang demokratis serta bertanggungjawab.

Dalam dunia pendidikan, peranan guru sangatlah penting, yakni orang yang bertanggungjawab mencerdaskan kehidupan anak didik, dan bertanggungjawab atas segala, sikap, tingkah laku dan perbuatan dalam rangka membina anak didik agar menjadi orang yang bersusila, cakap, dan berguna bagi nusa dan bangsa. Guru adalah pendidik profesional dengan tugas utama mendidik, mengajar, membimbing, mengarahkan, melatih, menilai, dan mengevaluasi peserta didik pada pendidikan anak usia dini jalur pendidikan formal, pendidikan dasar, dan pendidikan menengah (Peraturan menpan No. 16 tahun 2009).

Karena guru mempunyai peranan penting dalam dunia pendidikan, maka guru harus memiliki kinerja yang baik. Kinerja adalah tingkat keberhasilan seseorang atau kelompok orang dalam melaksanakan tugas dan tanggung jawabnya serta kemampuan untuk mencapai tujuan dan standar yang telah 
ditetapkan (Sulistiyoroni, 2001) . Sedangkan menurut Timple (1992) bahwa kinerja merupakan hasil dari fungsi pekerjaan atau kegiatan tertentu yang di dalamnya terdiri dari tiga aspek yaitu kejelasan tugas atau pekerjaan yang menjadi tanggung jawabnya; kejelasan hasil yang diharapkan dari suatu pekerjaan atau fungsi; dan kejelasan waktu yang diperlukan untuk menyelesaikan suatu pekerjaan agar hasil yang diharapkan dapat terwujud.

Untuk melihat dan menilai serta membantu kinerja guru agar semua kegiatan yang telah terprogram dapat berjalan secara efektif dan efisien serta sesuai dengan apa yang telah direncanakan diperlukan pengawasan atau supervisi oleh kepala sekolah. Hal ini sesuai dengan yang diungkapkan oleh Sahertian (2000: 19) bahwa pengawasan atau supervisi pendidikan tidak lain dari usaha memberikan layanan kepada stakeholder pendidikan, terutama kepada guruguru, baik secara individu maupun secara kelompok dalam usaha memperbaiki kualitas proses dan hasil pembelajaran.

Tujuan supervisi adalah membantu guru mengembangkan kemampuannya mencapai tujuan pembelajaran yang harus dicapai peserta didik. yaitu dengan peningkatan pengetahuan dan keterampilan guru mengajar, peningkatan komitmen (commitment), dan kemauan (willingness) serta motivasi (motivation) guru, sebab dengan meningkatkan kemampuan dan motivasi kerja guru, kualitas pembelajaran akan lebih meningkat (Sudjana, 2011:56) (dalam Ruswenda, 2011:42).

Supervisi atau pembinaan guru tersebut lebih menekankan pada pembinaan profesional guru yakni pembinaan yang lebih diarahkan pada upaya memperbaiki dan meningkatkan kemampuan profesional guru. Guru profesional memiliki kemampuan profesional dengan berbagai kapasitasnya sebagai pendidik (Jerry H. Makawimbang, 2011 : 134). Guru profesional memiliki pengalaman mengajar, kapasitas intelektual, moral, keimanan, ketakwaan, disiplin, tanggungjawab, wawasan kependidikan yang luas, kemampuan manajerial, terampil, kreatif, memiliki keterbukaan profesional dalam memahami potensi, karakteristik dan masalah perkembangan peserta didik, mampu mengembangkan rencana studi dan karir peserta didik serta memiliki kemampuan meneliti dan mengembangkan kurikulum. Mengacu pada penelitian ini, peneliti memilih SMA Negeri 1 Sembawa karena sekolah tersebut baru berdiri tahun 2012, dimana para gurunya banyak yang masih muda, belum mempunyai pengalaman yang luas tentang proses pembelajaran. 


\section{KAJIAN PUSTAKA}

Kepala dapat diartikan sebagai pemimpin dalam suatu organisasi atau lembaga, sedangkan sekolah adalah sebuah lembaga tempat menerima dan member ilmu pengetahuan kepada peserta didik. Menurut Kristiawan dkk (2017) kepala sekolah merupakan motor pengggerak, penentu arah kebijakan sekolah yang akan menentukan bagaimana tujuan-tujuan sekolah dan pendidikan pada umumnya direalisasikan. Menurut Permendiknas No 28 Tahun 2010 Kepala sekolah/madrasah adalah guru yang diberi tugas tambahan untuk memimpin taman kanak-kanak/raudhotul athfal (TK/RA), taman kanak-kanak luar biasa (TKLB), sekolah dasar/madrasah ibtidaiyah (SD/MI), sekolah dasar luar biasa (SDLB), sekolah menengah pertama/madrasah tsanawiyah (SMP/MTs), sekolah menengah pertama luar biasa (SMPLB), sekolah menengah atas/madrasah aliyah (SMA/MA), sekolah menengah kejuruan/madrasah aliyah kejuruan (SMK/MAK), atau sekolah menengah atas luar biasa (SMALB) yang bukan sekolah bertaraf internasional (SBI) atau yang tidak dikembangkan menjadi sekolah bertaraf internasional (SBI).

Salah satu kompetensi yang harus dimiliki seorang kepala sekolah sesuai dengan Permen diknas No 28 Tahun 2010 adalah kompetensi supervisi. Menurut Purwanto
(2002: 76), supervisi adalah tidak lain dari usaha memberi layanan kepada guru-guru baik secara individual maupun kelompok dalam usaha memperbaiki pengajaran. Sedangkan Supardi (2014: 76) mengartikan supervisi sebagai pelayanan untuk membantu, mendorong, membimbing, dan membina, guru-guru agar mampu meningkatkan kemampuan dan keterampilan dalam menjalankan tugas pembelajaran. Untuk melaksanakan supervisi ini, kepala sekolah harus memiliki 3 kompetensi supervise akademik, yaitu1) merencanakan program supervisi akademik dalam rangka peningkatan profesionalisme guru; 2) melaksanakan supervisi akademik terhadap guru dengan menggunakan pendekatan dan teknik supervisi yang tepat; dan 3) menindaklanjuti hasil supervisi akademik terhadap guru dalam rangka peningkatan profesionalisme guru (Permendiknas Nomor 13 Tahun 2007).

Kegiatan supervisi pendidikan merupakan kegiatan yang wajib dilaksanakan yang bertujuan memperbaiki pembelajaran guna meningkatkan hasil pembelajaran. Menurut Arikunto (2004) supervisi memiliki fungsi meningkatkan mutu pendidikan yang tertuju pada aspek akademik yang terjadi di kelas ketika guru sedang melaksanakan pembelajaran, memicu perubahan terkait dengan pendidikan yang tertuju pada unsurunsur yang berpengaruh terhadap peningkatan 
kualitas pembelajaran dan sebagai kegiatan dalam hal memimpin dan membimbing yaitu tertuju pada pelaksanaan supervisi diarahkan kepada guru dan tenaga tata usaha.

Agar supervisi tersebut dapat dilakukan dengan baik, harus dilaksanakan dengan prinsip- prinsip: rasa aman kepada pihak yang disupervisi, bersifat konstruktif dan kreatif, realistis didasarkan pada keadaan dan kenyataan sebenarnya, terlaksana dengan sederhana, terjalin hubungan professional bukan didasarkan atas hubungan pribadi, dan didasarkan pada kemampuan, kesanggupan, kondisi dan sikap pihak yang disupervisi, serta supervisi harus menolong guru agar senantiasa tumbuh sendiri tidak tergantung pada kepala sekolah. (Jerry H. Makawimbang, 2011:76). Dengan dilaksanakannya supervisi secara baik akan berdampak pada kinerja guru.

Dalam Undang-Undang Nomor 14 tahun 2005 Bab 1 pasal 1, disebutkan guru adalah pendidik profesional dengan tugas utama mendidik, mengajar, membimbing, mengarahkan, melatih, menilai, dan mengevaluasi peserta didik pada pendidikan anak usia dini jalur pendidikan formal, pendidikan dasar, dan pendidikan menengah.

Menurut Byars dan Rue (1991: 250) "Performance refers to degree of accomplishment of the tasks that make up an individual's job. It reflects how well an individual is fulfilling the requirements of a job”. Pendapat Byars dan Rue diartikan bahwa kinerja atau performance mengacu pada derajat tingkat penyelesaian tugas yang melengkapi pekerjaan seseorang. Hal ini mencerminkan seberapa baik seseorang dalam melaksanakan tuntutan suatu pekerjaan.

Persyaratan penilaian kinerja harus memenuhi ukuran atau standar tertentu. Artinya ukuran kinerja dilakukan sesuai dengan indikator kinerja sebagai alat ukur. Menurut Mitchell dan Larson (1987: 491) "Area of performance is quality of work, promptness, initiative, capability and communication". Artinya wilayah (indikator) penilaian kinerja adalah kualitas hasil kerja, ketepatan waktu menyelesaikan pekerjaan, inisiatif/prakarsa dalam menyelesaikan pekerjaan, kemampuan menyelesaikan pekerjaan, dan komunikasi/kemampuan membina kerjasama dengan pihak lain.

Penilaian kinerja seorang guru merupakan bagian penting dari seluruh proses kinerja guru yang bersangkutan. Menurut Martinis Yamin dan Maisah (2010: 117-125) beberapa sumber penilaian tenaga kependidikan adalah: (1) penilaian atas diri sendiri; (2) penilaian oleh siswa; (3) penilaian oleh rekan sejawat; dan (4) penilaian oleh atasan langsung. 


\section{METODE PENELITIAN}

Penelitian ini bermaksud untuk melihat bagaimana implementasi supervisi akademik kepala sekolah sebagai upaya peningkatan kinerja guru dalam meningkatkan mutu penidikan di SMA Negeri 1 Sembawa. Dalam penelitian ini, peneliti menggunakan metode deskriptif dengan pendekatan kualitatif yang bersifat fenomenologis yaitu menyelidiki suatu fenomena sosial atau masalah manusia. Menurut Sugiyono (2012: 1), metode penelitian kualitatif adalah metode penelitian yang digunakan untuk meneliti pada kondisi obyek yang alamiah dimana peneliti adalah sebagai instrumen kunci, teknik pengumpulan data dilakukan secara trianggulasi (gabungan), analisis data bersifat induktif dan hasil penelitian kualitatif lebih menekankan makna dari pada generalisasi.

Teknik pengumpulan data dalam penelitian kualitatif bersifat nauralistik (alamiah), yakni dengan observasi, wawancara, dan dokumentasi. Menurut Moleong (1991) data dalam penelitian kualitatif diperoleh melalui literature, observasi, dan wawancara serta dokumentasi kemudian dianalisis dan dikompromikan secara kritis. Adapun observasi sebagai metode ilmiah diartikan sebagai pengamatan dan pencatatan dengan sistematis atas fenomena-fenomena yang diteliti (Sutrisno, 2004). Sedangkan pengertian wawancara, menurut Nazir (1998) adalah proses memperoleh keterangan untuk tujuan penelitian dengan cara tanya jawab sambil bertatap muka antara si penanya atau pewawancara dengan si penjawab atau responden dengan menggunakan alat yang dinamakan interview guide (panduan wawancara).

Dalam penelitian ini yang diwawancarai adalah kepala sekolah dan guru- guru SMAN 1 Sembawa. Pertama peneliti melakukan wawancara dengan kepala sekolah yaitu Dra. Ernalia selanjutnya dengan guru-guru sebanyak 3 orang yaitu Nurhasana Hayati, S.Pd., Marlon Sijabat, S.Pd. dan Ida Purnama, S.T, M.Pd. Dalam wawancara yang dilakukan peneliti mengumpulkan informasi tentang bagaimana implementasi supervisi akademik di SMA Negeri 1 Sembawa kabupaten Banyuasin.

\section{HASIL PENELITIAN DAN PEMBAHASAN}

Berdasarkan hasil wawancara dengan kepala SMA Negeri 1 Sembawa didapatkan data bahwa dalam pelaksanaan supervisi akademik dilakukan dengan cara membuat perencanaan terlebih dahulu, selanjutnya melaksanakan, kemudian menindaklanjuti dari pelaksanaan supervisi tersebut. Dengan demikian pelaksanaan supervisi di SMA Negeri 1 Sembawa dilakukan melalui 3 (tiga) yaitu perencanaan, pelaksanaan, dan evaluasi. 
Hal ini sesuai dengan pendapat Asmendri (2012: 145-146) bahwa pelaksanaan supervisi terdiri dari tiga tahapan yaitu perencanaan, pelaksanaan, dan evaluasi.

Pada perencanaan supervisi ada beberapa hal yang harus dilakukan, yaitu penentuan tujuan, waktu pelaksanaan, dan pembuat jadwal supervisi. Dalam wawancara dengan kepala SMA Negeri 1 Sembawa, beliau mengatakan bahwa kegiatan dalam perencanaan adalah menetukan tujuan dan membuat jadwal yang tercantum dalam sebuah surat keputuan (SK) tentang supervisi akademik yang disertai dengan jadwal pelaksanaannya. Hal tersebut diperkuat dengan wawancara bersama guru-guru di SMA Negeri 1 Sembawa, yaitu; Nurhasana Hayati, S.Pd., Marlon Sijabat, S.Pd. dan Ida Purnama, S.T, M.Pd. . Mereka mengatakan bahwa sebelum dilaksanakan supervisi mereka telah mendapatkan surat keputusan (SK) tentang kegiatan supervisi akademik yang dilampiri jadwal pelaksanaan dari kepala sekolah. Hal tersebut dilakukan agar guru-guru dapat mempersiapkan diri dan mengetahui jadwal kapan akan disupervisi sesuai dengan waktu yang telah ditentukan. Kegiatan ini sesuai dengan pendapat Asmendri (2012: 145) bahwa hal yang harus dicantumkan dalam perencanaan supervisi adalah tujuan supervisi, alasan mengapa kegiatan tersebut dilaksanakan, bagaimana metode/teknik mencapai tujuan yang telah dirumuskan, siapa yang akan dilibatkan, waktu pelaksanaan, dan hal-hal yang diperlukan dalam pelaksanaannya serta bagaimana memperoleh hal-hal tersebut.

Dalam pelaksanaan supervisi pada SMA Negeri 1 Sembawa, ada dua metode supervisi yang digunakan, yaitu supervisi biasa (di luar kelas) dan supervisi klinis (dalam kelas). Supervisi biasa dilakukan dalam bentuk kegiatan yang dapat membantu guru dalam mengatasi kesulitan-kesulitan yang dihadapi guru seperti melakukan diskusi dan wawancara dengan guru. Hal ini tidak terjadwal namun terjadi secara mendadak atau disaat dibutuhkan oleh kepala sekolah maupun guru itu sendiri dalam memecahkan suatu persoalan. Supervisi klinis dilakukan sesuai dengan jadwal yang telah ditetapkan oleh sekolah sesuai dengan surat keputusan (SK) kepala sekolah sehingga guru-guru tidak terkejut di saat kepala sekolah masuk untuk melaksanakan supervisi tersebut. Dalam wawancara dengan Kepala SMA Negeri 1 Sembawa, pada supervisi klinis peneliti menemukan bahwa pelaksanaan dilakukan dengan cara langsung berada di dalam kelas saat guru-guru mengajar. Sebelum masuk kedalam kelas, kepala sekolah melakukan pra observasi berupa temu awal untuk melihat persiapan guru yang akan disupervisi, seperti menelaah RPP yang akan diajarkan kepada peserta didik pada saat supervisi klinis 
berlangsung. Setelah melakukan pengamatan dan memperhatikan bagaimana cara guru mengajar dan kesesuaian materi ajar dengan peserta didik, kepala sekolah memanggil guru ke ruangan untuk mendiskusikan hasil dari pengamatan yang telah dilakukan dan memberikan solusi dari permasalahan yang ada. Hal ini diperkuat juga dari hasil wawancara dengan seorang guru, yaitu Nurhasana Hayati, S.Pd., yang mengatakan bahwa metode yang dilakukan oleh kepala sekolah dalam pelaksanaan supervisi kadangkadang metode secara langsung ke dalam kelas dan juga di luar kelas. Untuk di dalam kelas atau supervisi klinis, kepala sekolah mengamati guru yang sedang mengajar dan memberikan penilaian terhadap guru tersebut. Sementara menurut Marlon Sijabat, S.Pd dan Ida Purnama, S.T., M.Pd. pelaksanaan supervisi klinis yang dilakukan oleh kepala SMAN 1 Sembawa adalah melakukan pengamatan langsung guru mengajar dan melakukan evaluasi terhadap kinerja guru. Kemudian guru-guru yang diwawancarai tersebut juga menyatakan pernyataan yang sama bahwa setelah melakukan pengamatan, mereka dipanggil oleh kepala sekolah keruangannya untuk mendiskusikan hasil dari pengamatan ketika supervisi klinis berlangsung. Kemudian kepala sekolah memberikan masukan dan solusi terhadap kelemahan guru pada saat supervise berlangsung. Dari hasil wawancara tersebut terdapat kesamaan dengan pendapat Asmendri (2012: 145), yang mengungkapkan bahwa pelaksanaan supervisi meliputi beberapa kegiatan yaitu pengumpulan data, penilaian, deteksi kelemahan, memperbaiki kelemahan, bimbingan dan pengembangan.

Selanjutnya evaluasi supervisi merupakan tahap penilaian setiap kegiatan yang dilaksanakan, apakah supervisi sudah sesuai dengan tujuan yang ditetapkan atau belum. Sampai mana pelaksanaan yang dilakukan di dalam proses keseluruhan organisasi mencapai hasil sesuai dengan rencana atau program yang telah ditetapkan dalam rangka pencapaian tujuan pendidikan (Asmendri, 2012: 22). Evaluasi supervisi lebih dikenal dengan tindak lanjut. Tindak lanjut yang dilaksanakan adalah apabila dalam pelaksanaan supervisi setelah diberikan masukan tetapi permasalahan tersebut masih belum bisa diatasi maka guru yang bersangkutan akan diikutsetakan dalam kegiatan ilmiah, seperti MGMP, workshop, pelatihan, seminar dan lain-lain. Hal tersebut dilakukan untuk meningkatkan pengetahuan dan ketrampilan guru. Kemudian dalam wawancara dengan guru-guru SMAN 1 Sembawa, yaitu; Nurhasana Hayati, S.Pd., Marlon Sijabat, S.Pd. dan Ida Purnama, S.T, M.Pd. Mereka mengatakan bahwa evaluasi dari pelaksanaan supervisi dilakukan guna 
meningkatkan kemampuan dan keterampilan guru.

Dari hasil wawancara yang telah dilakukan dengan kepala sekolah tentang tanggapan guru terhadap pelaksanaan supervisi, beliau mengatakan bahwa guru sangat merespon positif mengenai supervisi yang dilaksanakan oleh kepala sekolah. Hal ini diperkuat oleh Marlon Sijabat, S.Pd. yang mengatakan bahwa supervisi yang dilakukan oleh kepala sekolah itu penting, ini dikarenakan sudah menjadi tugas dari kepala sekolah dalam melakukan pengawasan terhadap guru-guru. Hal ini sesuai dengan hasil penelitian Jumadiah dkk (2016) yang menemukan bahwa guru sangat merespon supervisi akademik yang dilakukan kepala sekolah. Kemudian dari hasil wawancara dengan Nurhasana Hayati, S.Pd mengemukakan bahwa dengan dilaksanakannya supervisi bagi seorang guru, merupakan suatu yang sangat diharapkan sekali karena melalui supervisi akan dapat melihat sejauh mana kemampuan seseorang dalam melaksanakan tugasnya. Hal ini juga diperjelas oleh Ida Purnama, S.T., M.Pd., yang mengatakan bahwa pelaksanaan supervisi oleh kepala sekolah sangat perlu dilaksanakan, karena dapat mengubah kinerja guru menjadi lebih baik dan dapat memotivasi guru dalam rangka melaksanakan tugasnya untuk mencerdaskan anak bangsa. Hal ini sesuai dengan hasil penelitian Joni (2016) yang menyimpulkan bahwa supervisi sangat penting dilakukan oleh seorang kepala sekolah dalam rangka meningkatkan kualitas kerja seorang guru.

\section{KESIMPULAN}

Dalam implementasi supervisi akademik di SMAN 1 Sembawa dilakukan melalui 3 (tiga) tahap, yaitu perencanaan, pelaksanaan, dan evaluasi atau tindak lanjut dari supervisi tersebut. Dalam perencanaan, kepala sekolah menerbitkan surat keputusan (SK) yang dilampiri jadwal pelaksanaan supervisi. Dalam pelaksanaannya, kegiatan supervisi dilaksanakan dengan cara biasa (di luar kelas) dan klinis ( dalam kelas). Guru - guru SMAN 1 Sembawa merespon positif supervisi akademik oleh kepala sekolah karena kegiatan supervisi sangatlah penting dilakukan untuk mengubah kinerja guru menjadi lebih baik.

\section{DAFTAR PUSTAKA}

Arikunto, Suharsimi. (2004). Dasar-Dasar Supervisi. Jakarta: PT Rineka Cipta.

Byars, L. L., \& Rue, L. W., (1991). Human resources management. $\left(3^{\text {rd }} \mathrm{ed}\right)$. Boston: Irwin Inc.

Jerry H. Makawimbang (2011). Supervisi dan Peningkatan Mutu Pendidikan. Bandung, Alfabeta.

Joni (2016). "Pelaksanaan Supervisi Akademik Kepala Madrasah dalam Meningkatkan Kinerja Guru pada 
Madrasah Ibtidaiyah Swasta (MIS) Singkarak Kabupaten Solok". Jurnal Manajemen Kependidikan Al Fikrah Batusangkar. . Vol. IV, No. 2, Juli Desember 2016. ISSN: 2339-0131.

Jumadiah, Oktazil Nurdia, dkk. (2016). "Implementasi Supervisi Akademik Kepala MIS Batusangkar". Jurnal Manajemen Kepemimpinan dan Supervisi Pendidikan. Vol. 1 No. 1. Program Pascasarjana Universitas PGRI Palembang.

Kristiawan, M. Safitri, D. Rena L. (2017). Manajemen Pendidikan. Yogyakarta: Deepublish.

Martinis Yamin, \& Maisah. (2010). Standarisasi Kinerja Guru. Jakarta: GP Press.

Mitchell, T. R., \& Larson, J. R., jr. (1987). People in Organizations, an Introduction to Organizational Behavior $\left(3^{\text {rd }}\right.$ ed). Singapura : $\mathrm{Mc}$ Graw Hill Book Company.

Purwanto, M. Ngalim. (2002). Administrasi dan Supervisi Pendidikan. Bandung: Remaja Rosda Karya.

Peraturan Menpan dan Reformasi Birokrasi No. 16 Tahun 2009 tentang Jabatan Fungsional Guru dan Angka Kreditnya.

Permendiknas No. 13 tahun 2007 tentang Standar Kepala Sekolah.
Permendiknas No. 28 Tahun 2010 tentang Penugasan Guru Sebagai Kepala Sekolah.

Sahertian, Piet. (2000). Konsep-Dasar dan Teknik Supervisi Pendidikan Dalam rangka Pengembangan Sumber Daya Manusia. Jakarta: PT. Rineka Cipta.

Sulistyorini. (2001). Hubungan antara Keterampilan Manajerial Kepala Sekolah dan Iklim Organisasi dengan Kinerja Guru. Ilmu Pendidikan

Supardi. 2014. Kinerja Guru. Jakarta : Raja Grafindo.

Timple, A. Dale. (1992). Kinerja. Jakarta: PT. Gramedia Asri Media.

Undang-Undang No 14 Tahun 2005 tentang Guru dan Dosen.

Undang-Undang No. 20 Tahun 2003 tentang Sistem Pendidikan Nasional.

Usman, Nasir, (2007). Manajemen Peningkatan Kinerja Guru, Bandung: Mutiara Ilmu.

Uus Ruswenda (2011). Berbagai Faktor Dalam Supervisi Akademik Pengawas Sekolah Menengah Kejuruan (SMK) Di Kabupaten Kuningan. Tesis. Jakarta: Fakultas Ilmu Sosial dan Ilmu Politik Program Studi Ilmu Administrasi Kekhususan Administrasi dan Kebijakan Pendidikan. Universitas Indonesia. 